\title{
Effect of the filter-feeder silver carp on the water quality of fertilized earthen ponds and Nile tilapia production
}

\author{
Nabil A. Ibrahim
}

World Fish Center, Regional Center for Africa and West Asia, Abbassa, Abou-

Hammad, Sharkia, Egypt

\begin{abstract}
The objective of this study is to test the effect of silver carp on water quality and tilapia yield. This work was conducted in six $1000 \mathrm{~m}^{2}$ earthen ponds which randomly assigned to two treatments. The first treatment was the cultivation of Nile tilapia with silver carp and the second was the cultivation of Nile tilapia alone without silver carp. All ponds were fertilized for the first three months with cow manure, urea and superphosphate to maintain a level of $2 \mathrm{mg} \mathrm{N} / \mathrm{L}$ and $0.5 \mathrm{mg} \mathrm{P} / \mathrm{L}$ in pond waters. Water samples were collected weekly and analyzed for temperature, DO, $\mathrm{pH}, \mathrm{Chl}$. "a", avail. $\mathrm{P}, \mathrm{NO}_{3}, \mathrm{NH}_{4}, \mathrm{NH}_{3}, \mathrm{~T}$. Alk., and T. Hard. Two-way ANOVA results indicated that the effect of the experimental period was the most important source of variation for the water quality parameters and it was responsible for $47-100 \%$ of the variability for most of water quality parameters. The results also revealed that the presence of silver carp led to about $57 \%$ reduction of the chlorophyll concentration in the water column. Silver carp also was significantly responsible for $38 \%$ of the variability of the total alkalinity concentrations and for 5-26\% of the total variability for $\mathrm{pH}$, available phosphorus, ammonium, ammonia and total hardness however it was not significant. The results of factor analysis indicated that combined two factors (photosynthesis vs. respiration and pond fertilization) accounted for $40 \%$ of the total variability explained by the ANOVA model. The presence of silver carp reduced tilapia production by about $10 \%$, but it increased the total fish production which in turn resulted in $25 \%$ higher net profit (1009 LE/ha) than that in the case of absence of silver carp, which appeared also in the $\mathrm{B} / \mathrm{C}$ ratio of about $28 \%$ greater with the presence of silver carp than its absence. The stocking density of silver carp used in this study was not enough to obtain all benefits of cultivating silver carp with other fish species, therefore further trials are needed with different stocking densities.
\end{abstract}

Keywords: Silver carp; Nile tilapia; filter feeder; Water quality; Algal bloom

\section{INTRODUCTION}

Aquaculture production in Egypt has been increased at a rate of $11 \%$ per year through the last ten years with more than $72 \%$ contribution of the 2011 country total fish production (1362.174 thousand tons). This increase in aquaculture fish production increased the per capita consumption from 14.3 at 2002 to $19.1 \mathrm{~kg}$ at $2011,17 \mathrm{~kg}$ of them came from aquaculture (GAFRD, 2012).

The effect of filter-feeding fish on the plankton communities of aquatic ecosystem have been studied by Zhang et al. (2006); Milstein et al. (2008); Yan et al. (2009); Wahab et al. (2011) and others. Silver carp (Hypophthalmichthys molitrixon) have been introduced worldwide for both fish production and algal control (Gophen, 1990; Xie, 2003). Stocking of silver carp as a bio-manipulation tool to reduce phytoplankton biomass in lakes remains controversial (Starling et al., 1998; 
Domaizon and Devaux, 1999) as responses vary according to body size, stocking density, food availability, and environmental conditions (Spataru and Gophen, 1985).

Silver carp is expected to have a strong impact on the pond ecology, because it is a very efficient filter feeder (Milstein et al., 1985; Milstein, 1992), and also for human nutrition especially for people with lower incomes who are trying to eat a high nutritive animal protein with affordable prices, because of its cheap price compared to the other fish species or animal protein sources.

The present study aimed to test the effects of the filter-feeder silver carp on the water quality parameters through its effect on the algal blooms and its impact on the growth, survival and production of Nile tilapia, consequently its economic return.

\section{MATERIALS AND METHODS}

This work was conducted in six $1000 \mathrm{~m}^{2}$ earthen ponds at the WorldFish Center Abbassa Abou-Hammad Sharkia, Egypt for 195 days. All ponds were rectangular in shape with the same approximately average depth of $1.2 \mathrm{~m}$; water level was maintained at a water column of $1.0 \mathrm{~m}$.

\section{Experimental design}

Ponds were randomly allocated to two treatments with three replicates each. The first treatment was the cultivation of Nile tilapia with silver carp and the second was the cultivation of Nile tilapia alone without silver carp.

\section{Experimental fish}

Mixed sex fry of Nile tilapia (Oreochromis niloticus) were stocked in all ponds at the same stocking density of $2 \mathrm{fish} / \mathrm{m}^{2}$ (2000 fry/pond) with an average initial mean body weight of $0.2 \mathrm{~g}$. Silver carp (Hypophthalmichthys molitrix) fingerlings were stocked in the ponds of the first treatment only, at the rate of 0.025 $\mathrm{fish} / \mathrm{m}^{2}$ ( $25 \mathrm{fish} /$ pond) with an average initial body weight of $50 \pm 5 \mathrm{~g}$. Random fish samples were monthly taken throughout the experimental period and weighed to adjust feeding amounts then fish were returned to their corresponding ponds. All fish in all ponds were fed on an artificial fish feed $25 \%$ crude protein with the rate of $2 \%$ of the fish biomass for six days a week twice daily starting from the day 91 to the end of the experimental period.

\section{Pond fertilization}

Pond waters were analyzed weekly for total nitrogen and phosphorus then cow manure $(2 \% \mathrm{~N} \& 0.5 \% \mathrm{P})$, urea $(45 \% \mathrm{~N})$ and superphosphate $\left(15.5 \% \mathrm{P}_{2} \mathrm{O}_{5}\right)$ were used for the first three months of the experimental period to fertilize all ponds at the rate of $2 \mathrm{mg} \mathrm{N} / \mathrm{L}$ and $0.5 \mathrm{mg} \mathrm{P} / \mathrm{L}$ as recommended by Ibrahim (1997 and 2001); Nagdi et al. (2003); Ibrahim and Nagdi (2006) and El- Naggar et al. (2008).

\section{Water quality analyses}

Water samples were collected weekly from five spots in each pond and mixed together in one bucket, and then one litter was taken from the bucket as a representative water sample. Then the water samples were taken to the laboratory for the analysis of chlorophyll " $a$ " (Chl. " $a$ "), available phosphorus (Avail. P), nitrate $\left(\mathrm{NO}_{3}\right)$, ionized ammonia $\left(\mathrm{NH}_{4}\right)$, unionized ammonia $\left(\mathrm{NH}_{3}\right)$, total alkalinity (T. Alk.) and total hardness (T. Hard.) according to APHA (1998). Water temperature, early morning dissolved oxygen and $\mathrm{pH}$ values were measured twice a week in situ (at each pond).

\section{Economic evaluation}

A simple economic comparison was made to calculate the net profit and benefit/cost $(\mathrm{B} / \mathrm{C})$ ratio for the fish production with or without silver carp, based on 
the Egyptian local market prices and fish farm gate prices of 9.5, 8.25, 7, 5.5 and 3 $\mathrm{LE} / \mathrm{kg}$ of tilapia super, first, second, third and forth classes respectively, 5 and 9 $\mathrm{LE} / \mathrm{kg}$ for silver carp and catfish respectively.

\section{Statistical analysis}

Data were subjected to one-way analysis of variance to detect if significant differences occurred in the fish production parameters as affected by the presence or absence of silver carp. A two-way ANOVA was used to analyze water quality data with the two main effects being presence or absence of silver carp and the experimental period. Differences between means were assessed by Duncan's multiple range test and effects with a probability of $\mathrm{P} \leq 0.05$ were considered significant. Ecological processes that account for the main variability of the measured variables were identified through factor analysis as described by Kim and Mueller (1978); Kadir et al. (2006). The purpose of factor analysis is to explain the relationships among a set of variables in terms of a limited number of new variables (factors), which are assumed to be responsible for the most explained variance among the observed variables. The first factor extracted from that matrix is the linear combination of the original variables, which accounts for as much of the variation contained in the samples as possible. The second factor is the second linear function that accounts for most of the remaining variability, and so on. The factors are independent of one another and have no units. The coefficients of the linear functions defining the factors are used to interpret their meaning, using the sign and relative size of the coefficients as an indication of the weight to be placed upon each variable. All statistics were done using the Statistical Analysis System (SAS) version 9.1 (SAS, 2009).

\section{RESULTS AND DISCUSSION}

Silver carp is an efficient filter-feeder fish that consumes phytoplankton and zooplankton which in turn affects the nutrient availability of the water column (Yan et al., 2009; Wahab et al., 2011). In order to study the effect of silver carp on the water environment, some water quality parameters were measured and monitored throughout the experimental period. In the present study it was observed that ponds without silver carp had a deeper greenish color than those with silver; this deeper greenish color in case of the absence of silver carp was gradually increased throughout the experimental period. This observation was confirmed by the measurements of chlorophyll " $a$ " (Figure 1), as illustrated in this figure mean concentrations of chlorophyll " $a$ " in the ponds with silver carp started from $15 \mu \mathrm{g} / \mathrm{L}$ at the beginning of the experiment to reach about $40 \mu \mathrm{g} / \mathrm{L}$ at the end of the experiment, while its concentration increased in the absence of silver from $25 \mu \mathrm{g} / \mathrm{L}$ at the beginning of the experiment to reach about $71 \mu \mathrm{g} / \mathrm{L}$ at the end of the experiment, thus the presence of silver carp led to about 57\% reduction of the chlorophyll concentration in the water column. 


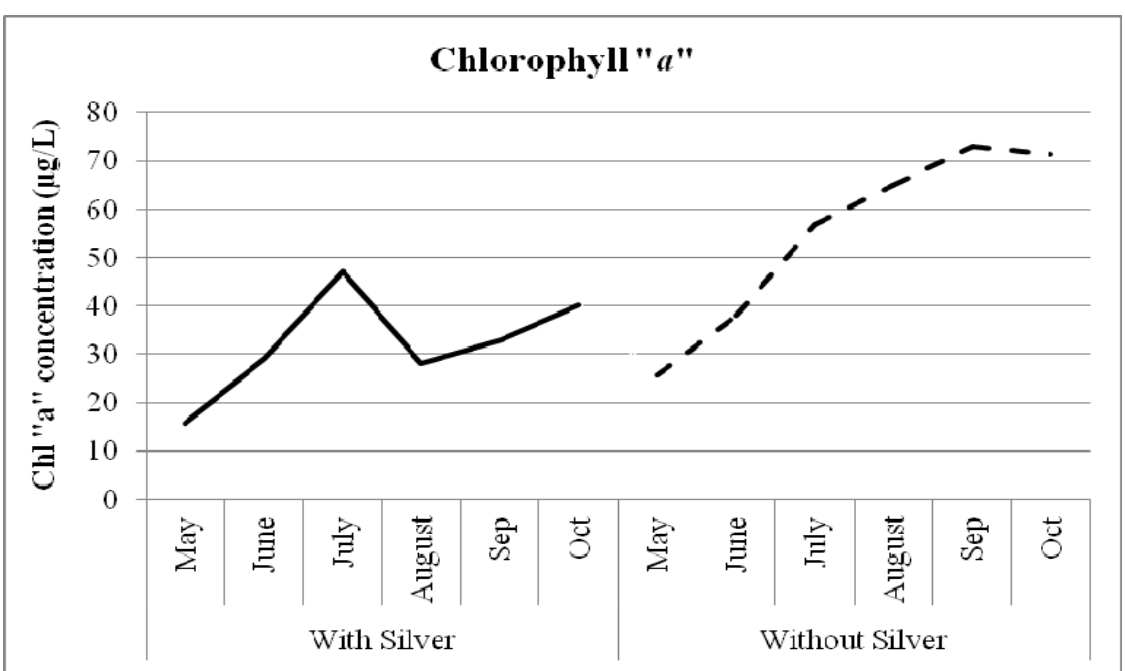

Fig. 1: Mean concentrations of chlorophyll " $a$ " throughout the experimental period in the presence or absence of silver carp.

Table (1) provides two-way analysis of variance of the measured water quality parameters. The model was highly significant for six of water quality parameters; water temperature, dissolved oxygen, $\mathrm{pH}$, available phosphorus, total alkalinity, and total hardness, while it was not significant for chlorophyll "a", nitrate, ammonium, and ammonia.

Table 1: Two-Way analysis of variance (ANOVA) and multicomparisons by Silver carp and period.

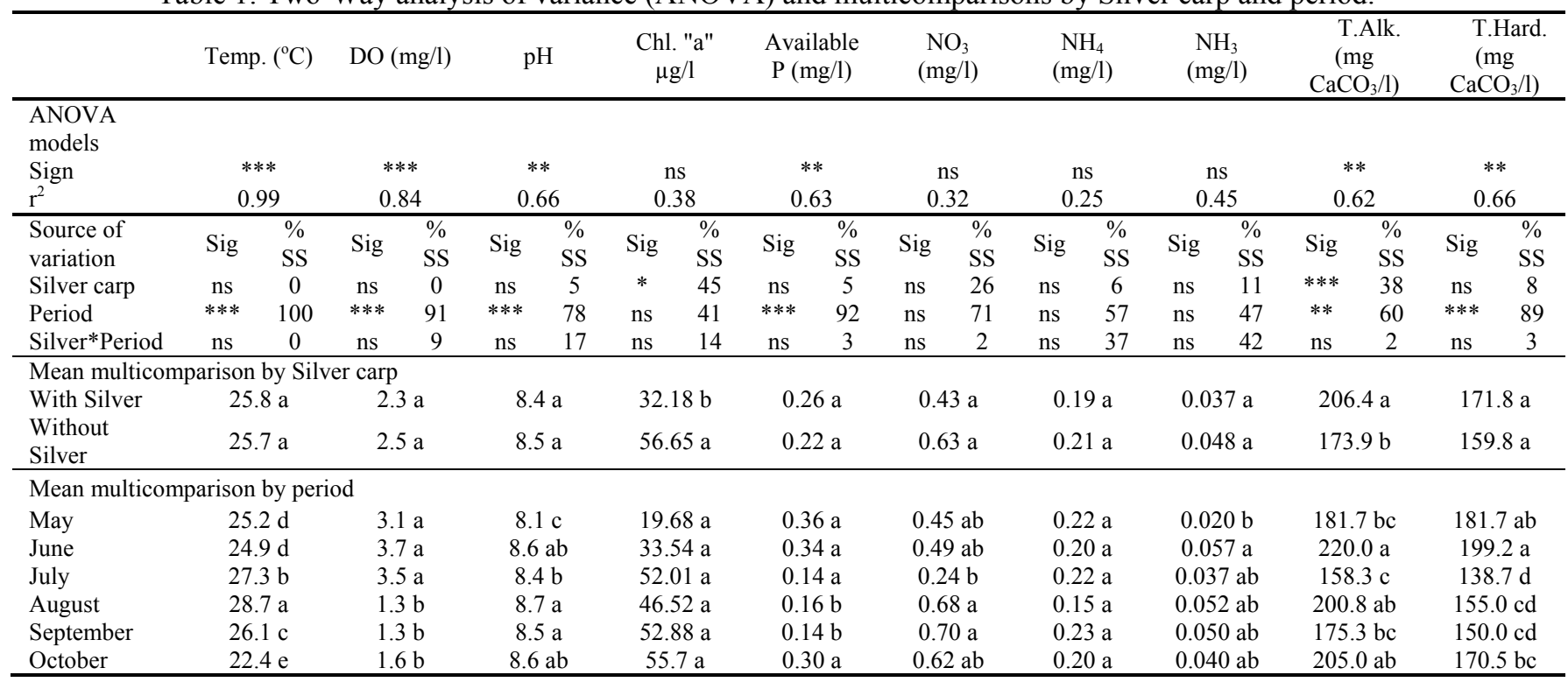

Sign $=$ significance level $* \mathrm{P} \leq 0.05,{ }^{* *} \mathrm{P} \leq 0.01,{ }^{* * *} \mathrm{P} \leq 0.001$, ns not significant. $\mathrm{r} 2$ determination coefficient.

$\% \mathrm{SS}=\%$ of sums of squares.

Means with the same letter in the same column are not significantly different (Duncan's multiple range test at $\mathrm{P}<0.05$ ).

The results from the ANOVA are presented as the proportion of total variation explained by each of the silver carp, the period or their interaction. The effect of the period was the most important source of variation for the water quality parameters and it was responsible for $47-100 \%$ of the total variability for all water quality parameters except for chlorophyll " $a$ " where silver carp was responsible for $45 \%$ of its variability. Ponds with silver carp had a significantly $(\mathrm{P}<0.05)$ lower average 
concentration of chlorophyll " $a$ " than ponds without silver as indicated by the Duncan letters in the multicomparison section of Table (1).

Silver carp was also responsible for $38 \%$ of the variability of total alkalinity concentration and it was significant, while it was responsible for 5-26\% of the total variability for $\mathrm{pH}$, available phosphorus, ammonium, ammonia and total hardness, but it was not significant as indicated by Duncan letters. This insignificant effect of the presence of silver carp may be due to the density of silver carp used in this study (250 fish/ha) were not sufficient to make a significant impact in all water quality parameters. These results are in agreement with those of Milstein et al. (2008) who found that the grazing pressure by the low density of silver carp (300-500 fish/ha) was not enough to affect other water quality parameters and minor effect on the availability of food for the other fish species occurred when the silver carp density was $1000 \mathrm{fish} / \mathrm{ha}$.

Figure (2) indicates more fluctuations in the concentration of the $\mathrm{pH}$ values in the absence of silver carp than that in the presence of silver carp; this most probably due to the photosynthesis process by phytoplankton cells, which had a significantly higher concentration in the absence of silver than that in the presence of it (56.7 and $32.2 \mu \mathrm{g} / \mathrm{L}$ chlorophyll " $a$ " respectively). Photosynthesis consumes $\mathrm{CO}_{2}$ from the water column which in turn reduces the $\mathrm{pH}$ values, while the respiration process increases $\mathrm{CO}_{2}$ again, that increases the $\mathrm{pH}$ value and so on, so the higher abundance of phytoplankton the higher fluctuations in the $\mathrm{pH}$ values as described by Ibrahim (2001), Suomela et al. (2005) and El Naggar et al. (2008).

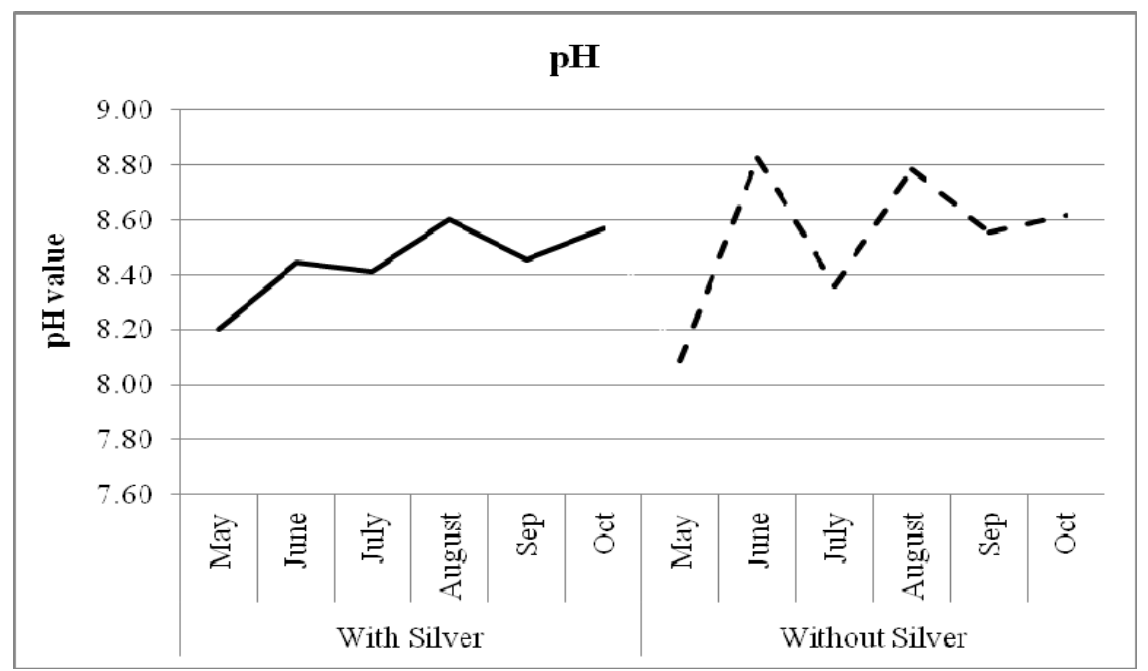

Fig. 2: Fluctuations of the mean concentration of $\mathrm{pH}$ throughout the experimental period in the presence and absence of silver carp.

These minor fluctuations in the concentrations of $\mathrm{pH}$ values in the first treatment (presence of the silver carp) compared to the second treatment (absence of the silver carp) may also refer to the higher concentrations of total alkalinity in the first treatment than in the second treatment (Table 1) as explained by Vinatea et al. (2010) who stated that high alkalinity concentrations reduces the fluctuation in $\mathrm{pH}$ values.

Figure (3) illustrates the fluctuations of water temperature and dissolved oxygen concentration and their reverse relationship. Water temperature reached its highest value of about $28.7^{\circ} \mathrm{C}$ in August for both treatments, while the concentration of the dissolved oxygen reached its lowest value in the same period (August) in both treatments, with slightly lower average concentration of dissolved oxygen in ponds 
with silver carp than that in ponds without silver carp ( 2.3 and $2.5 \mathrm{mg} / \mathrm{L}$ respectively), while it was insignificant.

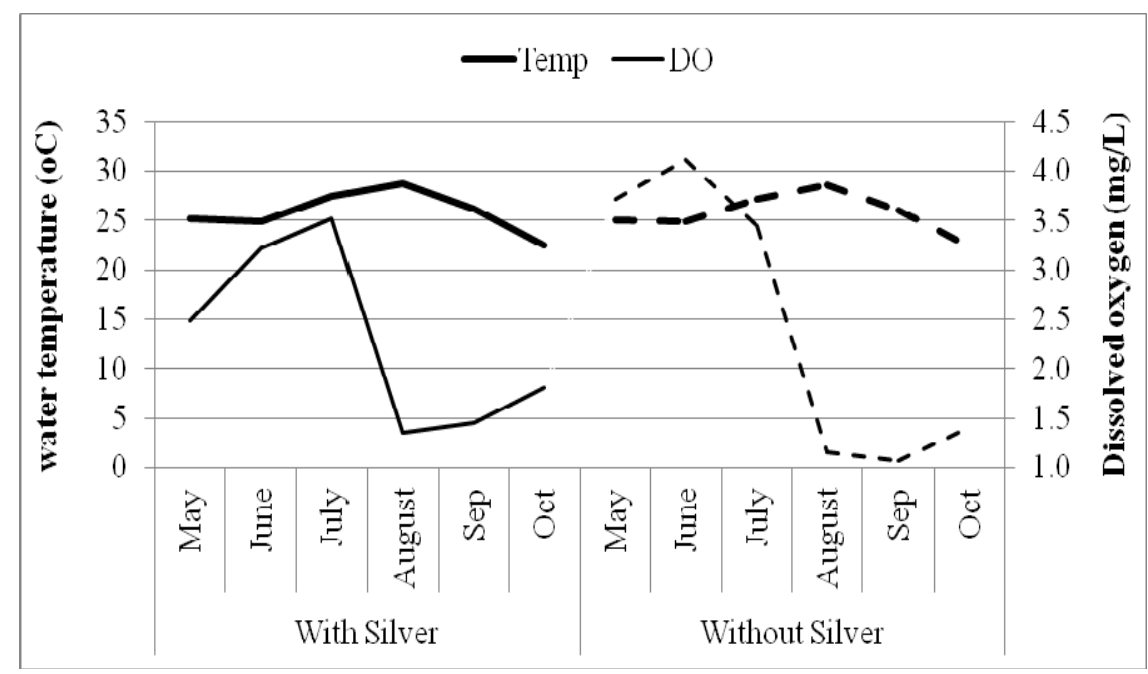

Fig. 3: Mean concentrations and fluctuations of water temperature and dissolved oxygen throughout the experimental period.

The results of factor analysis and the ANOVA test of factors with mean multicomparison analyses are presented in Table (2) and Figure (4). The mean multicomparisons show the effect of the silver carp and the experimental period for each factor. Combined two factors account for $40 \%$ of the total variability explained by the ANOVA model.

The first factor was responsible for $23 \%$ of the overall water quality variability, and had a negative correlation with water temperature, chlorophyll " $a$ ", and nitrate while it had a positive correlation with dissolved oxygen, available phosphorus and total hardness (Table 2). These correlations reflect the reverse relationship between photosynthesis and respiration. Where photosynthesis encourages by the availability of phosphorus "as a nutrient for phytoplankton" and it releases oxygen, while respiration happened with a higher extent at night times (when temperatures are low), and with lower concentrations of chlorophyll "a", and it releases $\mathrm{CO}_{2}$ which in turn increases water hardness as described by Boyd (1990) and Thorarensen \& Farrell (2011). The presence of silver carp was responsible for a small (15\%) but significant part of the total variability of the first factor, the period was responsible for $81 \%$ and it was also significant. The rest of the $4 \%$ was attributed to the interaction between silver carp and period while it was not significant.

The second factor was responsible for a further $17 \%$ of the explained water quality data variability. This factor shows a positive correlation with $\mathrm{pH}$, ammonium, ammonia and total alkalinity which reflects pond fertilization. As stated by Abdalla et al. (1996) and Ibrahim (2001) urea fertilizer breaks down to give ammonia and ammonium which in turn increases the $\mathrm{pH}$ value, while superphosphate contains calcium sulfate that increases the water alkalinity (Knud-Hansen, 1998). The ANOVA models indicate that the second factor (pond fertilization) was related to the period and not to the presence of silver carp. The period was responsible for $80 \%$ of the explained variance of this factor; the rest of $20 \%$ was attributed to the interaction between silver and period. 
Table 2: Results of factor analysis, ANOVA models and multicomparisons.

\begin{tabular}{lcc}
\hline Variable & Factor 1 & Factor 2 \\
\hline Temp. & $\mathbf{- 0 . 4 1 5}$ & -0.192 \\
$\mathrm{DO}$ & $\mathbf{0 . 3 0 1}$ & -0.023 \\
$\mathrm{pH}$ & -0.441 & $\mathbf{0 . 8 0 6}$ \\
$\mathrm{Chl}$ "a" & $\mathbf{- 0 . 4 7 9}$ & 0.064 \\
$\mathrm{Avai} . \mathrm{P}$ & $\mathbf{0 . 6 9 6}$ & 0.032 \\
$\mathrm{NO}_{3}$ & $\mathbf{- 0 . 0 5 3}$ & -0.052 \\
$\mathrm{NH}_{4}$ & -0.086 & $\mathbf{0 . 1 7 7}$ \\
$\mathrm{NH}_{3}$ & -0.440 & $\mathbf{0 . 7 4 2}$ \\
$\mathrm{T}$ alk & 0.437 & $\mathbf{0 . 4 5 6}$ \\
$\mathrm{T}$. hard & $\mathbf{0 . 8 6 2}$ & 0.499 \\
\hline \multirow{2}{*}{ Explained variance (\%) } & 23 & 17 \\
\hline Interpretation & Photosynthesis vs. & Pond Fertilization \\
\hline
\end{tabular}

Bold numbers are significant coefficients used for factor interpretation

ANOVA models

Significance level

$\mathrm{r}^{2}$

*** $\mathrm{ns}$

Mean multicomparison by Silver carp

$0.83 \quad 0.49$

With Silver

Without Silver

a $\quad$ a

Mean multicomparison by period

May a $\quad$ b

June $\quad \mathrm{ab} \quad \mathrm{a}$

July c c b

August $\quad$ c $\quad$ ab

September $\quad c \quad a b$

October b a

Significance level $* \mathrm{P} \leq 0.05, * * \mathrm{P} \leq 0.01, * * * \mathrm{P} \leq 0.001$ Different letters in the same column denote significant difference (Duncan's multiple range test at $\mathrm{P}<0.05$ ).

Figure (4) is a correlation chart provides all relationships between all water quality parameters on the light of factor 1 (photosynthesis vs. respiration) and factor 2 (pond fertilization), which responsible for about $40 \%$ of the total explained variance, as obtained by the factor analysis.

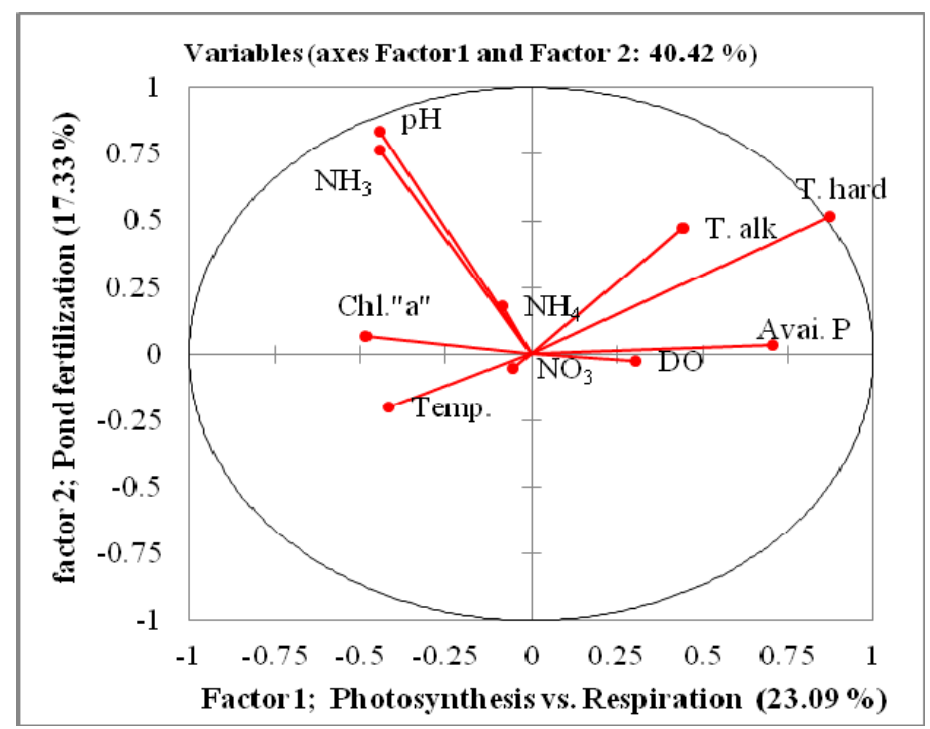

Fig. 4: Correlation chart of water quality parameters on the light of factors $1 \& 2$

Table (3) shows that the presence of silver carp has reduced tilapia production by about $10 \%$ (tilapia production was 3143.7 and $3458.3 \mathrm{~kg} / \mathrm{ha}$ in the presence and the 
absence of silver carp respectively). This reduction in tilapia production in the presence of silver carp, may be due to the fact that large amounts of phytoplankton, zooplankton and suspended particles (that used as a natural food for tilapia) were grazed by the efficient filter-feeder silver carp. In this connection Yan et al. (2009) and Wahab et al. (2011) found that in the water column intervention the increased silver carp grazing pressure on phytoplankton reduced food resources for other fish. In the present study these depleted resources may also affect the tilapia survival percentage by about $13 \%$ less in the presence of silver carp than that without silver carp. This gap of tilapia production was compensated in the grand total production by the production of silver carp of $384.3 \mathrm{~kg} / \mathrm{ha}$ and by the difference in the production of tilapia super class to be almost two folds in case of the presence of silver carp than in ponds without silver carp (tilapia super class production was 843 and $441.6 \mathrm{~kg} / \mathrm{ha}$ for the first and the second treatments respectively) (Table 3 and Figure 5).

Table 3: Fish production as affected by presence or absence of silver carp after 195 days.

\begin{tabular}{|c|c|c|c|}
\hline \multirow{2}{*}{\multicolumn{2}{|c|}{ Item }} & \multicolumn{2}{|c|}{ Treatment } \\
\hline & & With Silver carp & Without Silver carp \\
\hline \multirow{6}{*}{ 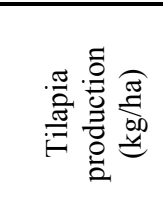 } & Super & $843.0^{\mathrm{a}} \pm 92.1$ & $441.6^{\mathrm{a}} \pm 163.4$ \\
\hline & $1^{\text {st }}$ class & $1098.7^{\mathrm{a}} \pm 65.2$ & $1329^{\mathrm{a}} \pm 95.1$ \\
\hline & $2^{\text {nd }}$ class & $662.0^{\mathrm{b}} \pm 18.8$ & $871.3^{a} \pm 63.8$ \\
\hline & $3^{\text {rd }}$ class & $460.3^{a} \pm 9.8$ & $635.0^{\mathrm{a}} \pm 86.5$ \\
\hline & $4^{\text {th }}$ class & $79.7^{\mathrm{a}} \pm 33.0$ & $181.0^{\mathrm{a}} \pm 88.3$ \\
\hline & Total & $3143.7^{b} \pm 19.1$ & $3458.3^{\mathrm{a}} \pm 33.1$ \\
\hline \multicolumn{2}{|c|}{ Silver carp $(\mathrm{kg} / \mathrm{ha})$} & $384.3 \pm 86.6$ & ---------- \\
\hline \multicolumn{2}{|c|}{ Catfish $(\mathrm{kg} / \mathrm{ha})$} & $16.7^{\mathrm{a}} \pm 10.1$ & $53.0^{\mathrm{a}} \pm 45.7$ \\
\hline \multicolumn{2}{|c|}{ Grand total (kg/ha) } & $3544.7^{\mathrm{a}} \pm 83.0$ & $3511.3^{a} \pm 36.6$ \\
\hline \multicolumn{2}{|c|}{ Tilapia survival (\%) } & $87.0^{\mathrm{b}} \pm 1.8$ & $99.8^{\mathrm{a}} \pm 1.7$ \\
\hline \multicolumn{2}{|c|}{ Silver survival (\%) } & $74.7 \pm 19.6$ & ---------- \\
\hline
\end{tabular}

Means with same letter in the same row are not significantly different $(\mathrm{P}>0.05)$

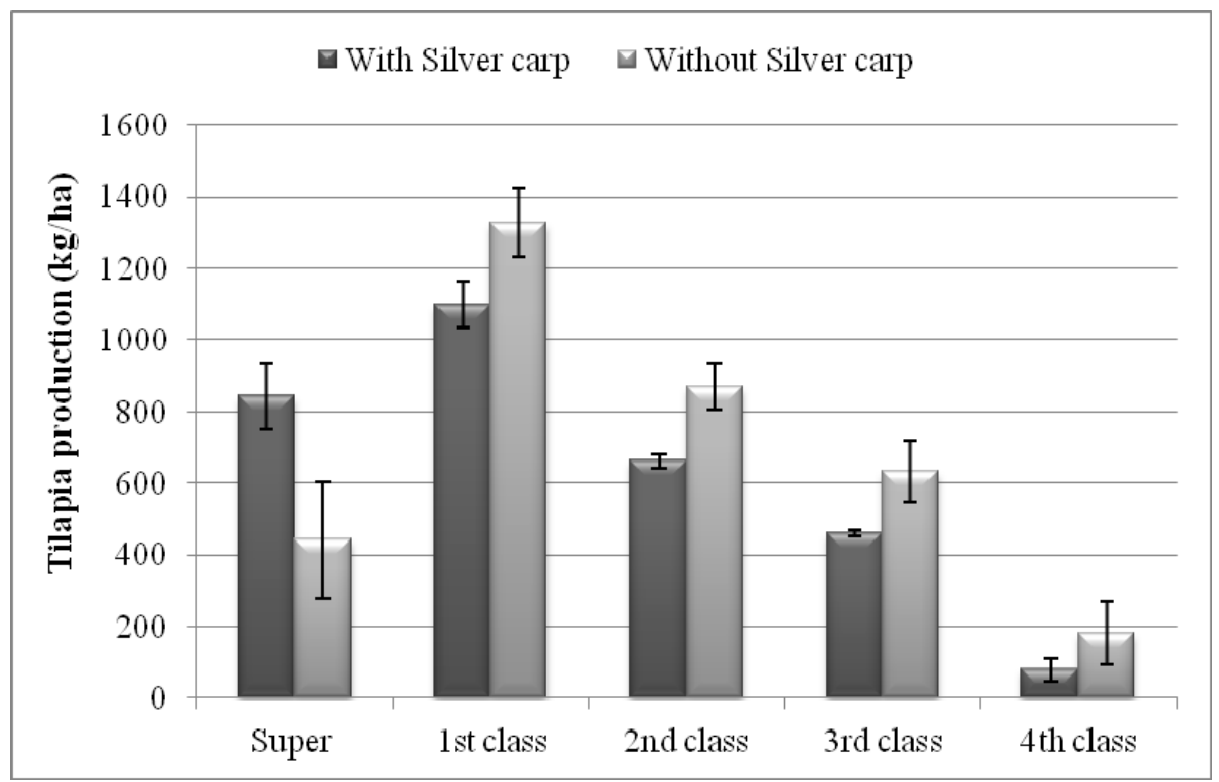

Fig. 5: Tilapia production by classes, super ( $\geq 300 \mathrm{~g})$, first (200-299 g), second (83-199 g), third (41-82 g) and fourth $(25-40 \mathrm{~g})$

Table (4) provides a simple economic comparison between the fish production either with or without silver carp. There was no significant difference in all economical parameters used in this study, except for tilapia production cost which was 6.87 and $6.31 \mathrm{LE} / \mathrm{kg}$ with and without silver carp respectively. This higher cost in tilapia production was due to the reduction in tilapia production as a result of the 
presence of silver carp. While total production cost showed no significant difference with slightly lower cost in the presence of silver carp. $(6.09$ and $6.21 \mathrm{LE} / \mathrm{kg}$ with and without silver carp respectively). Although insignificant difference in profit, the presence of silver carp resulted in 25\% higher net profit (1009 LE/ha) than that in case of absence of silver carp, which contributed in the $\mathrm{B} / \mathrm{C}$ ratio by about $28 \%$ greater than its absence. Similar results were found by Milstein et al. (2008) who reported that through its impact on the natural food web silver carp had several negative effects on the growth of the other fish, while the total yield and income increased, and by Kadir et al. (2006 and 2007) who stated that the strong negative effects of silver carp on the other species of the polyculture and the higher total yields and income recorded in the previous experiments with the addition of 10 silver carp $/ 100 \mathrm{~m}^{2}$.

Table 4: Simple economic comparison between fish performance with or without silver carp.

\begin{tabular}{cccccccc}
\hline Treatment & $\begin{array}{c}\text { Mean Sales } \\
\text { price (LE/kg) }\end{array}$ & $\begin{array}{c}\text { Tilapia } \\
\text { production } \\
\text { cost (LE/kg) }\end{array}$ & $\begin{array}{c}\text { Total } \\
\text { production } \\
\text { cost (LE/kg) }\end{array}$ & $\begin{array}{c}\text { Revenue } \\
(\mathrm{LE} / \mathrm{ha})\end{array}$ & $\begin{array}{c}\text { Total cost } \\
\text { (LE/ha) }\end{array}$ & $\begin{array}{c}\text { Net profit } \\
\text { (LE/ha) }\end{array}$ & $\begin{array}{c}\text { B/C } \\
\text { ratio }\end{array}$ \\
\hline $\begin{array}{c}\text { With Silver } \\
\text { carp }\end{array}$ & $7.49^{\mathrm{a}}$ & $6.87^{\mathrm{a}}$ & $6.09^{\mathrm{a}}$ & $26549^{\mathrm{a}}$ & $21581.1^{\mathrm{a}}$ & $4967.9^{\mathrm{a}}$ & $0.23^{\mathrm{a}}$ \\
\hline $\begin{array}{c}\text { Without } \\
\text { Silver carp }\end{array}$ & $7.34^{\mathrm{a}}$ & $6.31^{\mathrm{b}}$ & $6.21^{\mathrm{a}}$ & $25774^{\mathrm{a}}$ & $21815.3^{\mathrm{a}}$ & $3958.7^{\mathrm{a}}$ & $0.18^{\mathrm{a}}$ \\
\hline
\end{tabular}

Based on the obtained results it could be concluded that 1) Silver carp can be used as an efficient bio-manipulation fish, to reduce algal blooms which will reflect in a good impact on the water quality, 2) the addition of silver carp in tilapia ponds may decrease tilapia production but it increases the total fish production which in turn increases the net profit, 3) the stocking density of silver carp used in this study was not enough to obtain higher benefits of cultivating silver carp with other fish species, therefore further trials are needed with different stocking densities.

\section{REFERENCES}

Abdalla, A.A.; Clarence, D.; McNabb, C.D. and Batterson, T.R. (1996). Ammonia dynamics in fertilized fish ponds stocked with Nile tilapia. The progressive Fish Culturist, 58: 117-123.

APHA (American Public Health Association), (1998). StandardMethods for the Examination of Water and Wastewater, 20st edition. Washington, DC. 1193 pp.

Boyd, C. E. (1990). Water quality in ponds for aquaculture. Alabama Agriculture Experiment Station Auburn University, Alabama, USA Grobbelaar, 1983.

Domaizon, I. and Devaux, J. (1999). Experimental study of the impact of silver carp on plankton communities of eutrophic Villerest reservoir (France). Aquat. Ecol. 33: 193-204.

El-Naggar, G. O.; Ibrahim, N. A. and Abou Zead M. Y. (2008). Influence of fertilizers' types and stocking density on water quality and growth performance of Nile tilapia- African catfish polyculture system. The eighth international symposium on tilapia in aquaculture., pp. 157-171.

GAFRD (General Authority for Fish Resources Development). (2012). Annual report for country fish production in 2012.

Helgi Thorarensen, H. and Farrell, A. P. (2011). The biological requirements for postsmolt Atlantic salmon in closed-containment systems. Aquaculture 312: 1-14 
Ibrahim, N. A. (1997). Effect of different chemical fertilizers applied at a hyper dose on fish production. M. Sc. Thesis, Animal production dept., Faculty of Agriculture. Cairo Univ.

Ibrahim, N. A. (2001). Effect of Phytoplankton (Chlorella vulgaris and Scenedesmus spp.) Inoculation on Water Quality for Tilapia Culture by Urea and Superphosphate. Ph.D. Dissertation, Animal production dept., Fac. of Agri. Cairo Univ.

Ibrahim, N. A. and Nagdi, Z. A. (2006). Effect of nitrogen fertilizer source on water quality and performance of two tilapia species. Egypt. J. of Appl. Sci., 21 (6): $12-22$

Kadir, A.; Kundu, R.S.; Milstein, A. and Wahab, M.A. (2006). Effects of silver carp and small indigenous species on pond ecology and carp polycultures in Bangladesh. Aquaculture, 261: 1065-1076.

Kadir, A.; Wahab, M.A.; Milstein, A., Hossain, M.A. and Seraji, M.T.I. (2007). Effects of silver carp and the small indigenous fish mola Amblypharyngodon mola and punti Puntius sophore on fish polyculture production. Aquaculture, 273: 520-531.

Kim, J. O. and Mueller. C. W. (1978). Factor analysis. Statistical methods and practical issues. Quantitative applications in the social sciences, vol. 14. Sage University, Beverly Hills, California, USA. 8 pp.

Knud-Hansen, C. F. (1998). Pond fertilization ecological approach and practical application. Pond Dynamics / Aquaculture Collaborative Research Support Program, Oregon state Univ., Corvallis, Oregon 97331-1641. 125 pp.

Milstein, A. (1992). Ecological aspects of fish species interactions in polyculture ponds. Hydrobiologia, 231: 177-186.

Milstein, A.; Hepher, B. and Teltsch, B. (1985). Interactions between fish species and the ecological conditions in mono- and polyculture pond system. I. Phytoplankton. Aquaculture and Fisheries Management, 16: 305-317.

Milstein, A.; Kadir, A. and Wahab, M.A. (2008). The effects of partially substituting Indian carps or adding silver carp on polycultures of large carps and small indigenous fish species. Aquaculture, 279: 92-98.

Nagdi, Z. A.; Ibrahim N. A; Salem, M. and Shafie. M. M. (2003). Effect of phytoplankton inoculation with some chemical fertilizers on water quality and growth of tilapia in aquaculture. Egypt. J. of Phycol., 4: 1- 6.

Spataru, P. and Gophen, M. (1985). Feeding behavior of silver carp Hypophthalmichthys molitrixon Val. and its impact on the food web in Lake Cracken M. D. Kinneret, Hydrobiologia 120: 53-61.

Starling, F.; Beveridge, M.; Lazzaro, X. and Baird, D. (1998). Silver carp biomass effects on the plankton community in Paranoa reservoir (Brazil) and an assessment of its potential for improving water quality in lacustrine environments. Int. Rev. Hydrobiol. 83, 499-507.

Statistical Analyses Systems (SAS) (2009). SAS Program ver. 9.1, SAS institute incorporation, Cary, NC 27513 USA.

Suomela, J.; Gran, V.; Helminen, H.; Lagus, A.; Lehtoranta, J. and Sipura, J. (2005). Effects of sediment and nutrient enrichment on water quality in the Archipelago Sea, northern Baltic: An enclosure experiment in shallow water. Estuarine, Coastal and Shelf Science, 65: 337-350.

Vinatea, L.; Galvez, A. O.; Browdy, C. L.; Stokes, A.; Venero, J.; Haveman, J.; Lewis, B. L.; Lawson, A.; Shuler, A. and Leffler, J.W. (2010). Photosynthesis, water respiration and growth performance of Litopenaeus vannamei in a super- 
intensive raceway culture with zero water exchange: interaction of water quality variables. Aquacultural Engineering 42:17-24.

Wahab, M.A.; Kadir, A.; Milstein, A. and Kunda, M. (2011). Manipulation of species combination for enhancing fish production in polyculture systems involving major carps and small indigenous fish species. Aquaculture, 321: 289-297

Xie, P. (2003). Silver Carp and Bighead, and Their Use in the Control of Algal Blooms. Science Press, Beijing, 1-134 pp.

Yan, L.; Zhang, G.; Liu, Q. and Li, J. (2009). Optimization of culturing the freshwater pearl mussels, Hyriopsis cumingii with filter feeding Chinese carps (bighead carp and silver carp) by orthogonal array design. Aquaculture, 292:60-66

Zhang, X.; Xie, P.; Hao, L.; Guo, N.; Gong, Y.; Hu, X.; Chen, J. and Liang, G. (2006). Effects of the phytoplanktivorous silver carp (Hypophthalmichthys molitrixon) on plankton and the hepatotoxic microcystins in an enclosure experiment in a eutrophic lake, Lake Shichahai in Beijing. Aquaculture, 257: 173-186

\section{ARABIC SUMMARY}

\section{تأثير أسماك المبروك الفضى (المتفذى بالترشيح) على جودة المياه فى الأحواض الترابية المسمدة وإنتاج

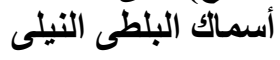

$$
\text { المركز الدولى للأسماك المركز، الإقليمى لأفريقيا وغرب إبرأسيا ـالعباسة ـأبو حمادـ شرقية - مصر }
$$

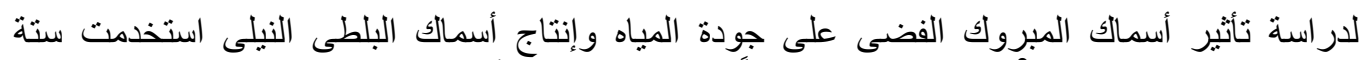

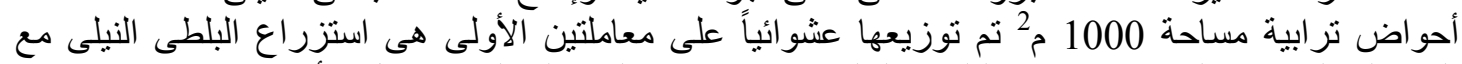

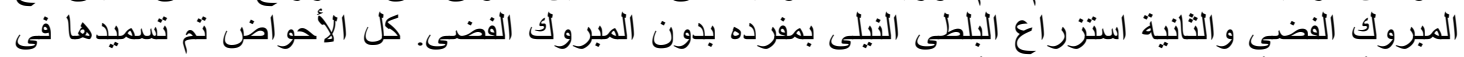

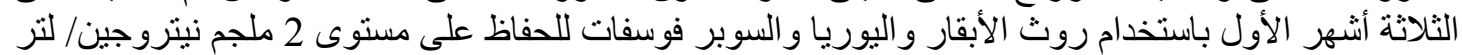

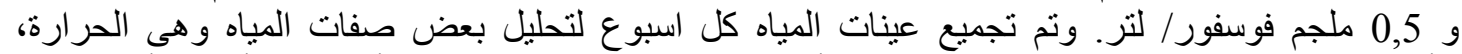

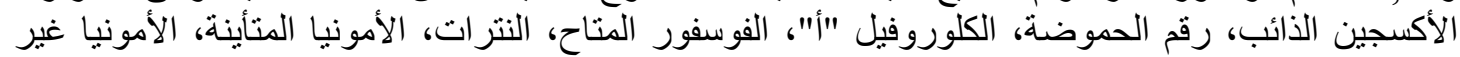

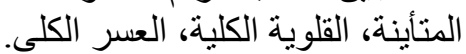
دل تحليل التباين ذو الاتجاهين أن تأثير فترة التجربة كان أهم مصادر التباين لمعايير جودة المياه وكان

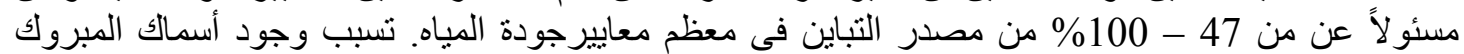

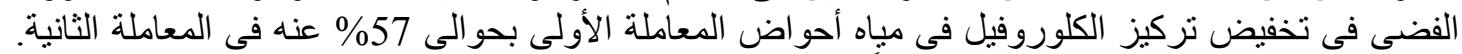

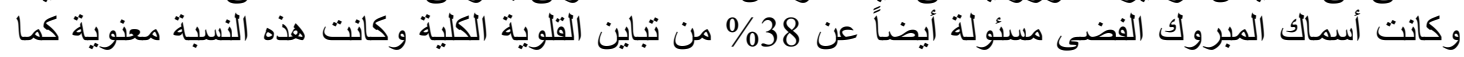

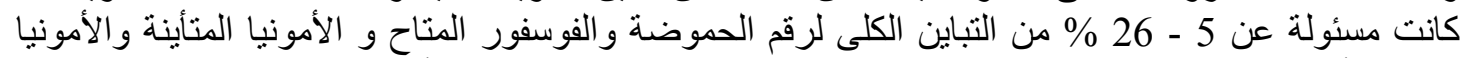

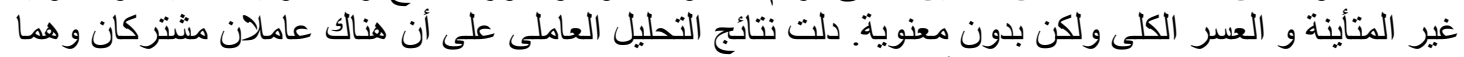

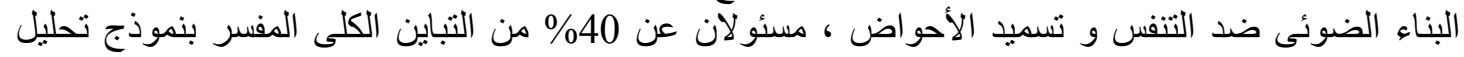

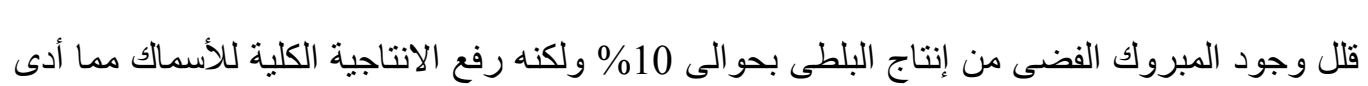

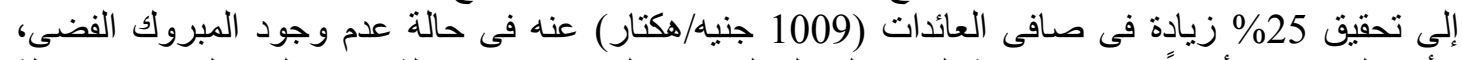
الأمر الذى ساهم أيضاً فى زيادة نسبة العائد على التكاليف بحو الى 28\% في حالة وجود المبروك عنه فى حالة

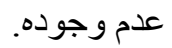

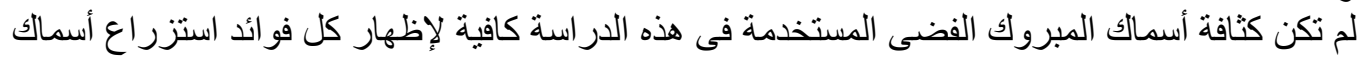

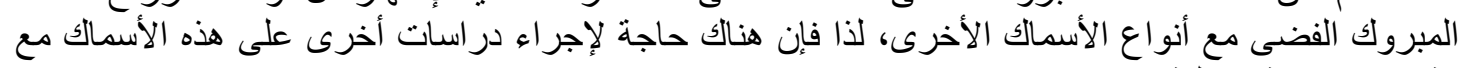

